\title{
PANCURONIUM AND HISTAMINE RELEASE
}

\section{R.I. BODMAN}

From the tIME of its introduction into anaesthesia pancuronium was said not to release histamine. In a definitive review of the pharmacology of pancuronium ${ }^{2}$ two references are quoted to support this view. One ${ }^{2}$ does not, in fact, contain the evidence quoted and the second, ${ }^{3}$ a report to a conference, has not been traced in the literature. Since then attempts have been made to compare the histamine releasing effects of d-tubocurarine and pancuronium by measuring plasma histamine levels ${ }^{4}$ and by measuring airway resistance. ${ }^{5}$ These workers concluded that pancuronium does not release histamine; consequently, this supposed advantage has been used to promote the use of pancuronium in preference to d-tubocurarine. However, four cases of bronchospasm following pancuronium have recently been reported in the literature ${ }^{\theta-9}$ and a fifth may have been attributable to this drug, although the writer preferred to incriminate thiopentone. ${ }^{10}$

A classical method of detecting histamine release in man is by the production of skin wheals by intradermal injection; as Paton remarks "intradermal injection is a valuable test ... which offers the advantage that a human tissue is used." This study provides a comparison of skin wheals produced by pancuronium and d-tubocurarine in man.

\section{METHOD}

These skin tests were undertaken with the sanction of the ethical committees of The General Hospital, St. John's, and the Medical School of Memorial University of Newfoundland. Fifty patients gave their consent to the tests, which were carried out while they were awaiting major operations for which a relaxant drug was to be used.

Equipotent doses of d-tubocurarine and pancuronium, with regard to muscle relaxation, were

R.I. Bodman, M.B., Ch.B., F.F.A.R.C.S., F.R.C.P.(C), Department of Anaesthesia, St. John's General Hospital, St. John's, Newfoundland, AlA IE5.

From the Department of Anaesthesia, Faculty of Medicine, Memorial University of Newfoundland.

Canad. Anaesth. Soc. J., vol. 25, no. 1, January 1978 assumed to be in the ratio of 5 to 1 . The dose of d-tubocurarine used was $0.15 \mathrm{mg}$ in $0.05 \mathrm{ml}$, as supplied by the manufacturer (Squibb) i.e. as 3 $\mathrm{mg}$ per $\mathrm{ml}$. The pancuronium (Organon) was supplied in a $2 \mathrm{mg}$ per $\mathrm{ml}$ solution; this was diluted with water to make $0.03 \mathrm{mg}$ in $0.05 \mathrm{ml}$.

The intradermal injections were made with 25-gauge needles on the anterior surface of the forearms, about two inches below the skin crease at the elbow, one drug on either side. The wheals were measured when they reached their maximum size, at about ten minutes. The outline was traced on the skin with a ball-point pen; thin millimeter-squared paper was damped lightly with a spirit swab and applied to the wheal with an even pressure. The outline of the wheal was thus transferred to the paper and the squares were counted.

\section{Results}

The mean age of the 50 subjects was $\mathbf{4 0 . 5}$ $( \pm 16.5)$ years. The areas of the wheals produced by d-tubocurarine was $157.3( \pm 47.4) \mathrm{mm}^{2}$ and by pancuronium was $88.1( \pm 21.0) \mathrm{mm}^{2}$. The differenco was significant: $\mathbf{P}<0.001$. Figure 1 illustrates these distributions.

\section{Discussion}

Comroe and Dripps ${ }^{12}$ were the first deliberately to inject curare intradermally. They stopped short of a quantitative assessment with the comment that "a sensitivity test for curare cannot be carried out by intracutaneous injection since 100 per cent of individuals tested developed wheals." In 1948, Bain, Hellier \& Warin ${ }^{13}$ showed that the areas of wheals and flares produced by histamine itself given intradermally were proportional to the log of the dose injected. Grob, Lilienthal \& Harvey ${ }^{14}$ measured the diameters of skin wheals and found that $0.135 \mathrm{mg}$ d-turbocurarine produced the same sized wheal as $0.1 \mathrm{mg}$ histamine. Bodman $^{15}$ first used this method on a new relaxant, when comparing laudexium with d-turbocurarine.

No deliberate study of pancuronium with respect to skin wheals seems to have been made in 


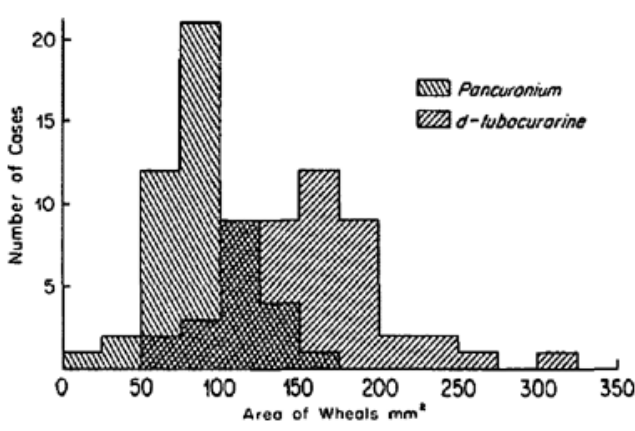

FIgURE I Areas of skin wheals produced by equipotent doses of $d$-tubocurarine and pancuronium.

man. Observers have contented themselves with remarks such as "no rash seen on the upper chest", ${ }^{16}$ no wheal formation seen "at the site of injection"." Attempts have been made to measure plasma histamine levels ${ }^{4}$ without conclusive results: this is not surprising as even during asthmatic attacks plasma histamine is not raised ${ }^{\text {B }}$

It would appear from the present findings that the claim that pancuronium did not release histamine was premature. Besides, four cases of bronchospasm following pancuronium have now been reported. ${ }^{6-9}$

Bain, et al. ${ }^{13}$ showed that skin wheals produced by histamine are dose related. Paton ${ }^{10}$ has made the point that "histamine release is the more readily produced the more rapid the injection". So far as the skin is concerned this is borne out by the clinical observation that when d-tubocurarine is injected directly into a vein in a concentration of $10 \mathrm{mg}$ per $\mathrm{ml}$ (as in Britain) flushing of the skin of the head, neck and upper chest is often seen, whereas this phenomenon is rarely seen in North America where the usual procedure is to use a $3 \mathrm{mg}$ per $\mathrm{ml}$ solution and to inject this into an intravenous line.

On the other hand the effect of d-tubocurarine on bronchial muscle is clearly not dose related; it has never been demonstrated that small doses do not cause bronchospasm while large doses always do. In fact, considering the popularity of the drug over 30 years, the incidence of bronchospasm must be very small, leading to the conclusion that it is a "sensitivity" phenomenon. Doubt is, in fact, being cast on the causal relationship of histamine and asthma ${ }^{17}$ : first, antihistamines $\left(\mathrm{H}^{1}\right.$ blockers) do not ameliorate or prevent asthmatic attacks, although they are effective against histamine released in the skin: secondly, plasma histamine is not raised during acute asthmatic attacks: a number of other autotic substances have been proposed, such as SRS-A, prostaglandins and the kinins. ${ }^{19}$

\section{SUMMARY}

Both d-tubocurarine and pancuronium release histamine in the skin: both have been shown to cause bronchospasm after intravenous injection. It is unlikely that skin testing with either drug will detect an individual susceptibility to bronchospasm, except as a non-specific test for atopy.

\section{RÉSUMÉ}

Le pancuronium, tout comme la tubocurarine en injection intradermique amène une libération d'histamine locale; on a par ailleurs rapporté des épisodes de bronchospasme avec les deux agents. Il est improbable qu'un test intradermique avant administration de l'un ou de l'autre agent permette la détection d'une susceptibilité individuelle à développer un bronchospasme à la suite de leur injection intraveineuse.

\section{REFERENCES}

1. Speight, T.M. \& Avery, G.S. Pancuronium bromide: a review of its pharmacological properties and clinical application, Drugs 4: 163-226 (1972).

2. Lund, I. \& StOVNER, J. Dose-response curves for tubocurarine, alcuronium and pancuronium. Acta anaesthesiologica Scandinavica Suppl. 37: 238 (1970).

3. Fukushima, K. \& Miyashita, K. Histamine blood levels following intravenous administration in anaesthetized subjects. Symposium on Pancuronium Bromide (Tokyo) (1970)

4. Dobkin, A.B., Arandia, H.Y., \& Levy, A.A. Effect of pancuronium bromide on plasma histamine levels in man. Anesth. \& Analg. 52: $772-775$ (1973).

5. CRAGo, R.R., BRYAN, A.C., LAWS, A.K., \& WINESTOCK, A.E. Respiratory flow resistance after curare and pancuronium, measured by forced oscillations. Canad. Anaesth. Soc. J., 19: 607-614 (1972).

6. BuCKLAND, R.W. \& AVERY, A.F. Histamine release following pancuronium. Brit. J. Anaesth. 45: 518-\$21 (1973).

7. Clark, R.M. Reaction to pancuronium? B rit. J. Anaesth. 45: 997 (1973).

8. HeATH, M.L. Bronchospasm in an asthmatic patient following pancuronium. Anaesthesia 28: $437-440$ (1973)

9. TWEEDIE, D.G. \& ORDISH, P.M. Reactions to intravenous agents. Brit. J. Anaesth. 46: 244 (1974).

10. Chung, D.C.W. Anaphylaxis to thiopentone. Canad. Anaesth. Soc. J. 23: 319-322 (1976). 
11. PATON, W.D.M. The effects of muscle relaxants other than muscular relaxation. Anesthesiology 20: 453-463 (1959).

12. Comroe, J.H. \& DriPPS, R.D. The histamine-like action of curare and tubocurarine injected intracutaneously and intra-arterially in man. Anesthesiology 7: 260-262 (1946).

13. BAIN, W.A., Hellier, F.F., \& WARIN, R.P. Some aspects of the action of histamine antagonists. Lancet $2: 964$ (1948).

14. Grob, D., Lilienthal, J.L., \& Harvey, A.M On certain vascular effects of curare in man: the histamine reaction. Bull. Johns Hopkins Hosp. 80: 299-322 (1947).

15. BODMAN, R.I. Evaluation of two synthetic curarizing agents in conscious volunteers. Brit. J. Pharmacol. 7: 409 (1952).
16. McDowell, S.A. \& Clarke, R.S.J. A clinical comparison of pancuronium with d-tubocurarine. Anaesthesia 24: 581-590(1969).

17. BAIRD, W.L.M. \& ReID, A.M. The neuromuscular blocking properties of a new steroid compound pancuronium bromide. Brit. J. Anaesth. 39: 775-780 (1967).

18. McСomss, R.P. Diseases due to immunologic reactions in the lungs. New Engl. J. Med. 286: 1186-1252 (1972).

19. Rose, B. \& Rodermecker, M. The pathogenesis of bronchial asthma, in immunological diseases, 2nd ed., p. 859, Ed M. Samter, Little Brown \& Co., Boston (1971). 